\title{
PROPORTIONAL SECRETION OF OPIOID PEPTIDES AND CATECHOLAMINES FROM ADRENAL CHROMAFFIN CELLS IN CULTURE
}

\author{
STEVEN P. WILSON, ${ }^{1}$ KWEN-JEN CHANG, AND O. HUMBERTO VIVEROS \\ Wellcome Research Laboratories, Research Triangle Park, North Carolina 27709
}

Received October 19, 1981; Revised February 22, 1982; Accepted March 1, 1982

\begin{abstract}
Bovine adrenal medullary chromaffin cells were used to study the relationship between opioid peptide and catecholamine secretion from the adrenal medulla. Stimulation of chromaffin cells by acetylcholine, nicotine, veratridine, barium, or Ionomycin produced secretion of opioid peptides and catecholamines which was proportional to the cellular content of these substances. Nicotine-evoked secretion of opioid peptides and catecholamines was dependent on extracellular calcium and was blocked by $d$-tubocurarine. Increased cellular content of opioid peptides and decreased catecholamine content induced by treatment of chromaffin cells with reserpine or tetrabenazine were reflected in the secretion of proportionally larger amounts of opioid peptides and smaller amounts of catecholamines when compared with secretion of these substances from untreated cells. Peptides of up to 25,000 daltons that express opiate activity only following digestion with enzymes, such as trypsin and carboxypeptidase B, also are secreted from chromaffin cells in the same proportion of their cellular content as are catecholamines and opioid peptides. Opioid peptides were secreted in proportion to total catecholamines but not in proportion to either epinephrine or norepinephrine alone, suggesting that the peptides are secreted from both epinephrine- and norepinephrine-containing cells in the cultures. The results are consistent with the co-storage of opioid peptides and opiate receptor-inactive peptides containing enkephalin sequences in chromaffin vesicles and with the allor-none exocytotic secretion of chromaffin vesicle content in response to stimulation of the adrenal medulla.
\end{abstract}

Met-enkephalin, Leu-enkephalin, and a variety of peptides that contain enkephalin sequences, including some which are inactive in standard opiate radioreceptor assays unless first digested with trypsin, are stored in subcellular organelles with a bouyant density equal to that of catecholamine storage vesicles in adrenal medullary chromaffin cells (Viveros et al., 1979; Lewis et al., 1980). These peptides and catecholamines (CAs) are cosecreted from the perfused adrenal gland (Viveros et al., 1979, 1980; Kilpatrick et al., 1980b) and from the adrenal in vivo (Viveros et al., 1980; Clement-Jones et al., 1980; Govoni et al., 1981). However, enkephalin-like peptides are localized not only in adrenal chromaffin cells but also in terminals of the splanchnic nerve in the adrenal medulla (Schultzberg et al., 1978) and proportional release of opioid peptides and CAs has not always been obtained (Viveros et al., 1979); hence, the cellular and subcellular

\footnotetext{
' To whom correspondence should be addressed at his current address: Department of Pharmacology, Duke University Medical Center, Durham, NC 27710.
}

sources of the peptides secreted from the intact adrenal have been questioned. Some of the conflicting findings may be the result of degradation or clearance through the lymphatic circulation of the peptides secreted from the perfused glands, complicating determination of the exact amounts secreted. Non-chromaffin cell types and other elements may influence secretion from perfused adrenals and from the adrenal gland in vivo.

Isolated, cultured bovine adrenal chromaffin cells have proven useful in the study of CA secretion (Fenwick et al., 1978; Mizobe et al., 1979; Kilpatrick et al., 1980a; Conn et al., 1980; Trifaró and Lee, 1980). These cells also synthesize and store opioid peptides (OPs) and larger peptides that contain enkephalin sequences (Wilson et al., 1980, 1981a; Rossier et al., 1981). The use of these chromaffin cell cultures to study OP secretion should avoid the problems associated with perfused glands and in vivo secretion noted above. Previous studies of $\mathrm{OP}$ secretion from adrenal chromaffin cells in culture (Stine et al., 1980; Livett et al., 1981) were limited in the number of secretagogues tested and in the size of the secretory responses observed. The secretion of opiate receptor- 
inactive peptides containing enkephalin sequences also has been shown (Rossier et al., 1981), but the secretory response was quite small and the proportionality of the secretion of these molecules with CAs and OPs was not addressed.

Our goal was to characterize the relationships between the adrenal medullary secretions of CAs, OPs, and peptides that express opiate activity only after enzyme digestion. In these studies, we used chromaffin cell cultures, maintained in a chemically defined medium, which retain their initial epinephrine, norepinephrine, and OP levels and the ability to secrete CAs for up to 3 weeks after plating (Wilson and Viveros, 1981; Wilson et al., 1981a). These cells also increase their OP content following treatment with CA-depleting drugs (Wilson et al., 1980, 1981a), allowing us to study the relationship between OP or CA cell content and evoked secretion of these substances. In addition, we investigated whether OPs are secreted from epinephrine- or norepinephrine-containing chromaffin cells. Preliminary reports of this work have appeared (Wilson et al., 1981b, c).

\section{Materials and Methods}

Materials. ${ }^{2}$ Acetylcholine chloride, nicotine, eserine sulfate, puromycin dihydrochloride, veratridine, carboxypeptidase $B$, and turkey egg white trypsin inhibitor were obtained from Sigma Chemical Co. $d$-Tubocurarine was obtained from INC-K \& K Laboratories. L-1-Tosylamido2-phenylethyl chloromethyl ketone (TPCK)-treated trypsin was obtained from Millipore Corp. Bio-Gel P-100 resin was obtained from Bio-Rad Laboratories. 8-Hydroxyquinoline was obtained from Eastman Kodak. Bacitracin was obtained from Schwarz/Mann. Kallikrein inactivator was obtained from Calbiochem. Met-enkephalin-Lys ${ }^{6}$ was obtained from Peninsula Laboratories. Tetrabenazine was obtained from Hoffmann-LaRoche. Reserpine was generously provided by Ciba Pharmaceutical as Serpasil phosphate. Ionomycin and Captopril were generous gifts from E. R. Squibb and Sons.

Cell culture. Chromaffin cells were isolated from bovine adrenal medullae and cultured in serum-free medium (Wilson and Viveros, 1981). The cells were cultured in Falcon MultiWell plates at a density of 0.5 to $1.0 \times 10^{6}$ cells $/ 2-\mathrm{cm}^{2}$ well.

Secretion experiments. Chromaffin cell cultures, 3 to 8 days after plating, were removed from the $\mathrm{CO}_{2}$ incubator and allowed to stand at $25^{\circ} \mathrm{C}$ for $10 \mathrm{~min}$. The culture medium then was removed by inverting the plate and 250 to $450 \mu \mathrm{l}$ of balanced salts medium $(150 \mathrm{mM}$ $\mathrm{NaCl}, 4.2 \mathrm{~mm}$ KCl, $1.0 \mathrm{~mm} \mathrm{NaH}_{2} \mathrm{PO}_{1}, 11.2 \mathrm{~mm}$ glucose, $10 \mathrm{~mm}$ HEPES, $0.7 \mathrm{~mm} \mathrm{MgCl}_{2}$, pH 7.4), containing 2.0 $\mathrm{mM} \mathrm{CaCl} 2$ (except as noted) and the secretagogues indicated, was added to each well by aligning the inverted, blotted plate containing the cell monolayers over a second MultiWell plate containing the media and then inverting both plates. After 10 to $90 \mathrm{~min}$ at $25^{\circ} \mathrm{C}$, the plates were inverted again and both the cells and the collected

\footnotetext{
${ }^{2}$ We wish to thank Dr. N. Kirshner for providing the veratridine and Ionomycin, Mr. F. Soroko for providing the tetrabenazine, and Dr. $\mathrm{S}$. Wilkinson for providing the Met- and Leu-enkephalin used in these studies.
}

media were placed on ice. The medium was adjusted to $0.1 \mathrm{M}$ acetic acid by adding an appropriate aliquot of 1.0 $M$ acid; each cell monolayer was extracted with $250 \mu \mathrm{l}$ of $1.0 \mathrm{M}$ acetic acid. The acidified secretion media and the acid extracts of the cells were subsequently analyzed for their CA and OP content.

This method of measuring secretion is very reliable and only small amounts of the secretion media are lost during the plate inversions, with no mixing between culture wells. The presence of $\mathrm{MgCl}_{2}$ in the secretion medium had no effect on the basal or nicotine-evoked secretion of CAs.

Trypsin/carboxypeptidase B digestion. Aliquots $(5 \mu \mathrm{l})$ of acid cell extracts were adjusted to $\mathrm{pH} 7.6$ to 7.8 with Tris base in a final volume of $40 \mu \mathrm{l}$. TPCK-treated tryspin ( $5 \mu \mathrm{l}$ of $10 \mu \mathrm{g} / \mathrm{ml}$ ) was added and the samples were incubated for $20 \mathrm{~min}$ at $37^{\circ} \mathrm{C}$. Carboxypeptidase B ( $5 \mu \mathrm{l}$ of $10 \mu \mathrm{g} / \mathrm{ml}$ ) then was added, and the incubation was continued for $10 \mathrm{~min}$. The samples were removed from the water bath and immediately processed for the radioreceptor assay except that turkey egg white trypsin inhibitor ( $1 \mu \mathrm{g} / 250 \mu \mathrm{l}$, final incubation volume) was added with the rat brain membrane suspension. Standards were treated similarly.

Other methods. The catecholamines, epinephrine and norepinephrine, were determined fluorometrically by the method of Anton and Sayre (1962) without initial purification on alumina. Opiate activity was determined by displacement of ${ }^{125} \mathrm{I}-\left[\mathrm{D}-\mathrm{Ala}^{2}, \mathrm{D}-\mathrm{Leu}^{5}\right]$ enkephalin from rat brain membrane receptors (Chang and Cuatrecasas, 1979; Wilson et al., 1981a). Leu-enkephalin was used as the standard.

\section{Results}

The secretion of OPs and CAs from cultured chromaffin cells was estimated by two methods. First, OPs and CAs were measured in the medium at the end of the secretion period. The amounts of OPs and CAs in the medium from cells exposed only to the balanced salts solution without secretagogues (basal release) were subtracted from the corresponding values in the medium of cells exposed to the secretagogue to obtain evoked secretion. Basal CA release varied from 1 to $5 \%$ of the cellular content; when measured, basal OP release also fell within this range. Second, the secretion of OPs and CAs was estimated by the difference between the content of unstimulated cells (no secretagogue) and the content of cells exposed to a secretagogue for a fixed period of time.

The results of an experiment in which OP and CA secretion was measured by these two methods are shown in Table I. In response to stimulation by acetylcholine, nicotine, or barium, large quantities of CAs and OPs were secreted as determined by both methods. The secretion of CAs was similar when determined by the two methods. Although, in this experiment, CA secretion was slightly lower when determined by the loss of cellular content than by its appearance in the medium, in other experiments, CA secretion measured by both methods was identical. In the case of OP secretion, however, significant differences between the amounts secreted determined by the two methods were observed for nicotine- and bariumevoked secretion; more OPs were lost from the cells than 
TABLE I

Catecholamine and opioid peptide secretion determined by appearance in the medium and by loss of cellular content

Chromaffin cells were exposed to the indicated secretagogues for 20 $\min$. Eserine $(10 \mu \mathrm{M})$ was present when acetylcholine was used; $2 \mathrm{mM}$ $\mathrm{Ca}^{2+}$ was present when acetylcholine and nicotine were tested. Both media and cell extracts were assayed for catecholamines and opioid peptides. The cell contents of catecholamines and opioid peptides were $119 \mathrm{nmol}$ and $34 \mathrm{pmol}$, respectively. Basal release (no secretagogue present) was subtracted to obtain the values shown as "Found in Medium." The basal release of catecholamines was $1.7 \pm 0.1 \mathrm{nmol}$ with $\mathrm{Ca}^{2+}$ in the medium and $1.3 \pm 0.3 \mathrm{nmol}$ without $\mathrm{Ca}^{2+}$; the basal release of opioid peptides was $0.24 \pm 0.03$ pmol with $\mathrm{Ca}^{2+}$ in the medium and $0.93 \pm 0.10 \mathrm{pmol}$ without $\mathrm{Ca}^{2+}$. The data are expressed as the mean \pm $\mathrm{SEM} ; n=3$.

\begin{tabular}{lcccc}
\hline \multirow{2}{*}{ Secretagogue } & \multicolumn{2}{c}{ Catecholamines } & \multicolumn{2}{c}{ Opioid Peptides } \\
\cline { 2 - 5 } & $\begin{array}{c}\text { Found in } \\
\text { Medium }\end{array}$ & $\begin{array}{c}\text { Lost from } \\
\text { Cells }\end{array}$ & $\begin{array}{l}\text { Found in } \\
\text { Medium }\end{array}$ & $\begin{array}{c}\text { Lost from } \\
\text { Cells }\end{array}$ \\
\hline & \multicolumn{2}{c}{ nmol } & \multicolumn{2}{c}{$p m o l$} \\
$50 \mu \mathrm{M}$ acetylcholine & $34.8 \pm 0.6$ & $30.5 \pm 2.5$ & $9.6 \pm 0.1$ & $10.1 \pm 0.9$ \\
$10 \mu \mathrm{M}$ nicotine & $34.5 \pm 0.1$ & $29.4 \pm 0.7$ & $7.4 \pm 0.2$ & $9.2 \pm 1.2$ \\
$2 \mathrm{mM} \mathrm{Ba}{ }^{2+}$ & $54.7 \pm 1.4$ & $50.3 \pm 2.0$ & $9.4 \pm 0.1$ & $13.1 \pm 0.5$ \\
\hline
\end{tabular}

TABLE II

Effect of peptidase inhibitors on nicotine-evoked secretion of catecholamines and opioid peptides

Chromaffin cells were tested for secretion, with or without $10 \mu \mathrm{M}$ nicotine, in the presence of the indicated peptidase inhibitor. The period of stimulation was $30 \mathrm{~min}$. The inhibitors had little or no effect on the catecholamine and opioid peptide assays or on the basal release of these substances. Basal release was subtracted from the nicotineevoked release before calculation of the percentage of control. Control secretion was determined without peptidase inhibitors and was equal to $9.7 \pm 1.2 \mathrm{nmol}$ of catecholamines and $6.4 \pm 0.3 \mathrm{pmol}$ of opioid peptides. The data are shown as the mean \pm SEM; $n=2$.

\begin{tabular}{lll}
\hline \multirow{2}{*}{ Inhibitor } & \multicolumn{2}{c}{$\begin{array}{c}\text { Percent Control } \\
\text { Secretion }\end{array}$} \\
\cline { 2 - 3 } & $\begin{array}{c}\text { Catecho- } \\
\text { lamines }\end{array}$ & $\begin{array}{c}\text { Opioid } \\
\text { Peptides }\end{array}$ \\
\hline $500 \mu \mathrm{M}$ 8-hydroxyquinoline & $21 \pm 2$ & $22 \pm 3$ \\
$20 \mu \mathrm{M}$ bacitracin & $40 \pm 2$ & $42 \pm 5$ \\
$20 \mu \mathrm{M}$ puromycin & $85 \pm 5$ & $69 \pm 19$ \\
200 units/ml of kallikrein inactivator & $76 \pm 1$ & $86 \pm 9$ \\
$200 \mu \mathrm{M}$ Captopril & $65 \pm 6$ & $44 \pm 5$ \\
\hline
\end{tabular}

appeared in the medium. In a separate experiment, only 35 to $60 \%$ of the OPs lost from cells during stimulation with nicotine was found in the medium. These differences suggest that OPs may be degraded following secretion from chromaffin cells, similar to the results reported for perfused adrenal glands (Viveros et al., 1980). Because of the variable degradation of secreted OPs and because added peptidase inhibitors inhibited chromaffin cell secretion (Table II), studies were carried out in the absence of peptidase inhibitors and OP secretion was estimated by the loss of cell content in all subsequent experiments, while CA secretion was estimated by both methods. Very similar results for CA secretion determined by the two methods were always obtained; only those values measured by the loss of cellular CA content are given.

Proportional secretion of opioid peptides and catecholamines. A number of secretagogues, which act by different mechanisms, induced secretion of chromaffin cell CAs and OPs (Table III). The physiological secretagogue, acetylcholine, evoked secretion of an equal percentage of the cellular stores of CAs and OPs. Nicotine evoked CA and OP secretion to the same extent as did acetylcholine (both were tested at concentrations maximally effective for CA secretion, i.e., 10 and $50 \mu \mathrm{M}$, respectively). Nicotine-evoked secretion of both CAs and OPs was dependent on the addition of calcium ions to the extracellular medium and was blocked by the nicotinic acetylcholine receptor antagonist, $d$-tubocurarine. Veratridine, an activator of voltage-dependent sodium channels, also induced proportional secretion of CAs and OPs as did barium. The calcium ionophore, Ionomycin, evoked OP and CA secretion (Table III, experiment II), although the response is much slower than that of the other secretagogues (not shown). The response to Ionomycin $(20 \mu \mathrm{M})$ was also dependent on extracellular calcium ions (not shown).

The treatment of chromaffin cell cultures for 3 days with reserpine resulted in a marked depletion of cellular CA content and in an elevated content of OPs (Table IV, experiment I) as reported (Wilson et al., 1980, 1981a). Tetrabenazine, also an inhibitor of CA uptake into chromaffin vesicles, produced a similar effect (Table IV, experiment II) at the maximally effective concentration of $100 \mu \mathrm{M}$. When reserpine- or tetrabenazine-treated cells were stimulated with nicotine, CA secretion was decreased and OP secretion was increased, relative to that of untreated cells, in proportion to the changes in the cellular content of these substances. This was true not only when maximally effective nicotine concentrations were used but also when half-maximally effective concentrations of nicotine ( $3 \mu \mathrm{M})$ were tested (not shown).

Secretion of peptides with cryptic opiate activity. Bovine adrenal chromaffin cells contain, in addition to

\section{TABLE III}

Co-secretion of catecholamines and opioid peptides from chromaffin cells

Cultured chromaffin cells were tested for secretion in the presence of the secretagogues indicated for 20 (experiment I) or $90 \mathrm{~min}$ (experiment II). When acetylcholine was used as the secretagogue, $10 \mu \mathrm{M}$ eserine was included. $d$-Tubocurarine was added to the culture medium $10 \mathrm{~min}$ before adding the secretion medium and was present throughout the secretion experiment. The calcium concentration in the medium was $2 \mathrm{~mm}$ for experiment I and $5 \mathrm{~mm}$ for experiment II. The data are expressed as the mean $\pm \mathrm{SEM} ; n=3$.

\begin{tabular}{|c|c|c|c|}
\hline \multirow[b]{2}{*}{ Secrelagugue } & \multirow[b]{2}{*}{$\mathrm{Ca}^{3+}$} & \multicolumn{2}{|c|}{ Percent Cell Content Secreted } \\
\hline & & Catecholamines & $\begin{array}{c}\text { Opioid } \\
\text { Peptides }\end{array}$ \\
\hline \multicolumn{4}{|l|}{ Experiment I } \\
\hline $50 \mu \mathrm{M}$ acetylcholine & + & $25.1 \pm 2.0$ & $27.6 \pm 2.5$ \\
\hline $10 \mu \mathrm{M}$ nicotine & + & $24.2 \pm 0.6$ & $27.1 \pm 2.6$ \\
\hline $10 \mu \mathrm{M}$ nicotine & - & 0 & 0 \\
\hline $\begin{array}{l}10 \mu \mathrm{M} \text { nicotine }+10 \\
\mu \mathrm{M} d \text {-tubocurarine }\end{array}$ & + & 0 & 0 \\
\hline $200 \mu \mathrm{M}$ veratridine & + & $19.3 \pm 1.4$ & $18.8 \pm 1.5$ \\
\hline $2 \mathrm{mM} \mathrm{Ba}^{2+}$ & - & $42.4 \pm 1.7$ & $44.7 \pm 1.7$ \\
\hline \multicolumn{4}{|l|}{ Experiment II } \\
\hline $20 \mu \mathrm{M}$ Ionomycin & 1 & $48.0 \pm 1.5$ & $48.1 \pm 1.5$ \\
\hline
\end{tabular}


TABLE IV

Proportional secretion of catecholamines and opioid peptides from chromaffin cells treated with reserpine or tetrabenazine Chromaffin cells were used 3 days after the indicated additions of $100 \mathrm{nM}$ reserpine or $100 \mu \mathrm{M}$ tetrabenazine to the culture medium. Cells were stimulated with $20 \mu \mathrm{M}$ nicotine for $10 \mathrm{~min}$ (experiment I) or $10 \mu \mathrm{M}$ nicotine for $20 \mathrm{~min}$ (experiment II). Cell contents represent the amounts of catecholamines and opioid peptides present in unstimulated cells after the incubation period. Nicotine-evoked secretion values are the losses in cell content evoked by the exposure to nicotine. The data are expressed as mean \pm SEM; $n=3$ for experiment I and $n=6$ for experiment II. The ratio indicates the quotient of the drug-treated value over the untreated value.

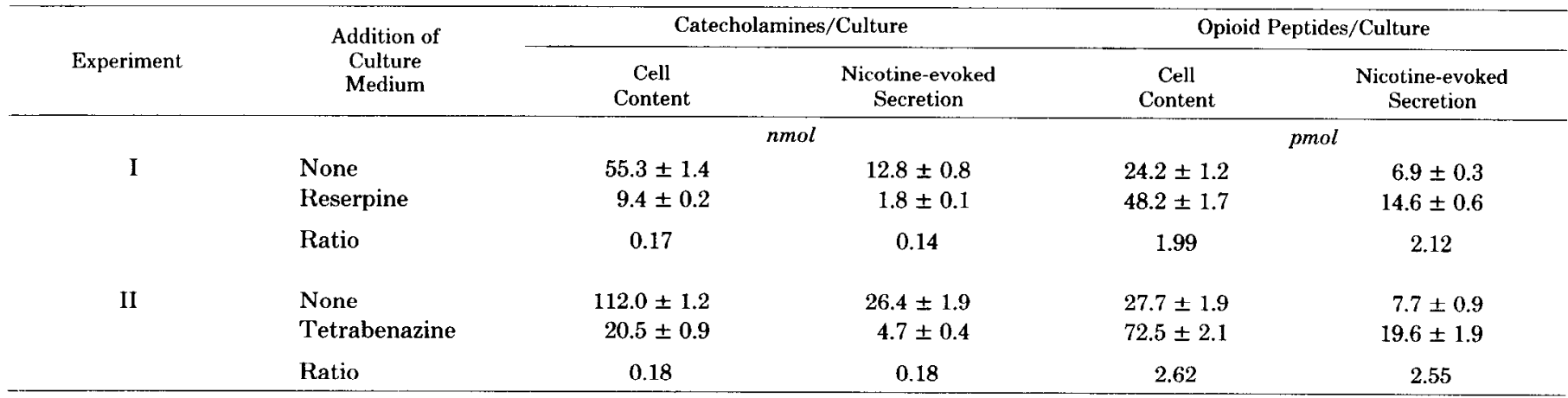

opioid peptides, peptides which have internal enkephalin sequences but which are not active in standard opiate radioreceptor assays without prior enzyme treatment (Lewis et al., 1980; Rossier et al., 1981). Preliminary experiments indicated that the procedure described under "Materials and Methods" for treating samples with trypsin and carboxypeptidase B and subsequently assaying for opiate activity was highly reliable for measuring the cryptic opiate activity of these peptides. Chromaffin cell samples treated with trypsin $(1.1 \mu \mathrm{g} / \mathrm{ml})$ for $10 \mathrm{~min}$ at $37^{\circ} \mathrm{C}$ showed no further increase in opiate activity following incubation up to $6 \mathrm{hr}$. Treatment with higher concentrations of trypsin did not produce further increases in the opiate activity of the samples. The presence of trypsin (up to $2.8 \mu \mathrm{g} / \mathrm{ml}$ ) had no inhibitory effect on the ability of carboxypeptidase B to convert a Metenkephalin-Lys ${ }^{6}$ standard (radioreceptor assay $\mathrm{IC}_{50}=16$ nM) to a species indistinguishable from Met-enkephalin $\left(\mathrm{IC}_{50}=3 \mathrm{nM}\right)$ in its affinity for the opiate receptor. Activation (increase in opiate activity) of trypsin-treated chromaffin cell extracts by carboxypeptidase B was not prevented by the presence of trypsin. Carboxypeptidase B $(1.0 \mu \mathrm{g} / \mathrm{ml})$ completely activated Met-enkephalin-Lys ${ }^{6}$ or trypsin-treated chromaffin cell samples within $5 \mathrm{~min}$ at $37^{\circ} \mathrm{C}$; longer incubations or higher enzyme concentrations failed to enhance these activations. Indeed, incubations with carboxypeptidase $B$ of $60 \mathrm{~min}$ or longer reduced the opiate activity of trypsin-treated chromaffin cell extracts. Treatment of cell extracts with carboxypeptidase $B$ alone produced little or no increase in opiate activity.

Stopping the enzyme digestions by boiling (Lewis et al., 1980) often resulted in losses of opiate activity; hence, we characterized the effects of trypsin and carboxypeptidase $\mathbf{B}$ on the radioreceptor assay in order to determine the opiate activity of the enzyme-treated samples directly. Carboxypeptidase B had no effect on the subsequent displacement by Leu-enkephalin standards of ${ }^{125} \mathrm{I}$ $\left[\mathrm{D}-\mathrm{Ala}^{2}, \mathrm{D}-\mathrm{Leu}^{5}\right]$ enkephalin from opiate receptors or on the total or specific binding of the radioligand. Trypsin $(1.1$ to $5.6 \mu \mathrm{g} / \mathrm{ml})$ had variable effects on the radioreceptor assay, including increasing or decreasing specific bind- ing and altering the apparent affinity of Leu-enkephalin for the receptor, but inclusion of turkey egg white trypsin inhibitor prevented these trypsin-induced alterations. Therefore, the enzyme-treated sample could be assayed without boiling or further dilution.

The treatment of chromaffin cell extracts with trypsin and carboxypeptidase $B$ resulted in 2- to 5 -fold more opiate activity in the extracts (Fig. 1; Table V). Gel filtration of cell extracts on Bio-Gel P-100 showed that approximately $70 \%$ of the opiate activity revealed by treatment with trypsin and carboxypeptidase $B$ resided in molecules that chromatographed as would be expected

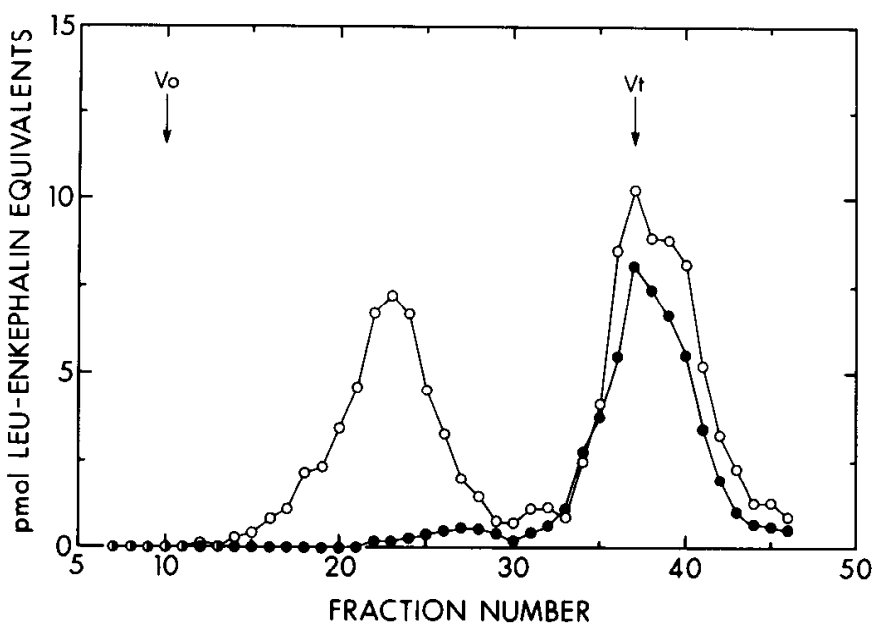

Figure 1. Gel filtration of an adrenal chromaffin cell extract. Chromaffin cells $\left(1.75 \times 10^{6}\right)$ were extracted with $1.0 \mathrm{M}$ acetic acid. The extract was neutralized with an equal volume of 1.2 $M$ Tris and was applied to a $0.9 \times 10 \mathrm{~cm}$ column of Bio-Gel P100 (100 to 200 mesh). The column was eluted with $50 \mathrm{~mm}$ Tris$\mathrm{HCl}, \mathrm{pH} 8.1\left(4^{\circ} \mathrm{C}\right)$, at a flow rate of $5 \mathrm{ml} / \mathrm{hr}$. Fractions of 520 $\mu \mathrm{l}$ were collected. The void volume of the column $\left(V_{0}\right)$ was determined by chromatography of blue dextran and ferritin. The total volume of the column $\left(V_{i}\right)$ was determined by the elution positions of Tris buffer and sucrose. Aliquots of the fractions were assayed for opiate activity with no further treatment (O) or following treatment by trypsin and carboxypeptidase $\mathrm{B}(\mathrm{O})$. Recoveries were approximately $90 \%$ compared to the unfractionated extract. 
for proteins of 8,000 to 25,000 daltons (Fig. 1). Peptides containing cryptic opiate activity were secreted from cells stimulated with nicotine (Table V); this secretion was proportional to both OP and CA secretion. Similar results were obtained when cells were stimulated with barium or Ionomycin.

Opioid peptides secreted with epinephrine and norepinephrine. High $\mathrm{K}^{+}$, veratridine, and nicotine were more potent in inducing norepinephrine than epinephrine secretion from the chromaffin cell cultures (Table VI). Opioid peptide secretion, expressed as the percentage of the cellular content released, was significantly different from norepinephrine secretion for each of the three secretagogues and significantly different from epinephrine secretion stimulated by veratridine and nicotine. The secretion of OPs was not significantly different

\section{TABLE V}

Secretion of peptides with cryptic opiate activity from chromaffin cells

Chromaffin cells were incubated with or without $10 \mu \mathrm{M}$ nicotine for $20 \mathrm{~min}$. The incubation medium was removed, and the cells were extracted with $1.0 \mathrm{M}$ acetic acid. Aliquots of these extracts were neutralized and assayed for opiate activity before and after treatment with trypsin and carboxypeptidase $B$. The difference between the opiate activity of the samples with and without enzyme treatment is shown as $\Delta$. The values shown as "Nicotine-evoked Secretion" represent the differences in the cell content between unstimulated and nicotinestimulated cells. Catecholamine secretion was $24.2 \pm 0.6 \%$ of cellular content. The data are shown as the mean \pm SEM; $n=3$.

\begin{tabular}{crcr}
\hline \multirow{2}{*}{$\begin{array}{c}\text { Enzyme } \\
\text { Treatment }\end{array}$} & \multicolumn{2}{c}{ Leu-enkephalin Equivalents/Culture } & Percent \\
\cline { 2 - 3 } & $\begin{array}{c}\text { Unstimulated } \\
\text { Cell Content }\end{array}$ & $\begin{array}{c}\text { Nicotine-evoked } \\
\text { Secretion }\end{array}$ & $\begin{array}{c}\text { Secreted } \\
\text { Sent }\end{array}$ \\
\hline & & pmol & \\
- & $33 \pm 2$ & $9 \pm 1$ & $27 \pm 3$ \\
+ & $158 \pm 9$ & $43 \pm 5$ & $27 \pm 3$ \\
$\Delta$ & $125 \pm 7$ & $34 \pm 4$ & $28 \pm 4$ \\
\hline
\end{tabular}

\section{TABLE VI}

Secretion of epinephrine, norepinephrine, and opioid peptides from chromaffin cells

Chromaffin cells were tested for secretion of epinephrine $(E)$, norepinephrine (NE), and opioid peptides (OPs) in the presence of the secretagogues indicated. For secretion induced by $50 \mathrm{~mm} \mathrm{~K}^{+}, \mathrm{KCl}$ replaced an equal concentration of $\mathrm{NaCl}$. The chromaffin cell catecholamine composition was $64 \pm 1 \%$ epinephrine $(n=24)$. The data are expressed as mean $\pm \mathrm{SEM} ; n=3$.

\begin{tabular}{lcccc}
\hline \multirow{2}{*}{ Secretagogue } & \multicolumn{4}{c}{ Percent Content Secreted in $20 \mathrm{Min}$} \\
\cline { 2 - 5 } \multicolumn{1}{c}{$\mathrm{E}$} & $\mathrm{NE}$ & $\mathrm{E}+\mathrm{NE}$ & OPs \\
\hline $50 \mathrm{mM} \mathrm{K}^{+}$ & $15 \pm 1$ & $31 \pm 1$ & $21 \pm 2^{a+}$ & $18 \pm 2^{b}$ \\
$100 \mu \mathrm{M}$ veratridine & $19 \pm 1$ & $50 \pm 1$ & $31 \pm 2$ & $34 \pm 2^{b, c}$ \\
$5 \mu \mathrm{M}$ nicotine & $19 \pm 1$ & $50 \pm 2$ & $31 \pm 1$ & $32 \pm 3^{\prime, c}$
\end{tabular}

"There was no significant difference between epinephrine plus norepinephrine and opioid peptide secretion for any of the secretagogues.

" $p<0.005$, statistically significant difference between norepinephrine and opioid peptide secretion.

$" p<0.005$, statistically significant difference between epinephrine and opioid peptide secretion.

" $p<0.02$, statistically significant difference between epinephrine and opioid peptide secretion.

" $p<0.01$, statistically significant difference between norepinephrine and opioid peptide secretion. from total CA secretion (epinephrine plus norepinephrine) for any of the secretagogues. When epinephrine, norepinephrine, and OP secretion were studied as a function of nicotine concentration, the potency of nicotine to induce norepinephrine secretion was greater than for epinephrine secretion (Fig. 2). The concentration of nicotine required for half-maximal norepinephrine secretion was less than that for epinephrine secretion. The doseresponse curve for $\mathrm{OP}$ secretion was significantly different from the individual dose-response relationships of epinephrine and norepinephrine secretion but was superimposable on the dose-response curve for total CA release.

\section{Discussion}

These results demonstrate the proportional secretion of OPs, peptides containing cryptic opiate activity, and CAs from bovine adrenal chromaffin cells in culture. This co-secretion is consistent with the vesicular storage of these molecules (Viveros et al., 1979) and confirms the exocytotic nature of adrenal medullary secretion (Viveros et al., 1969). These results also suggest that $\mathrm{OPs}_{\mathrm{s}}$ are secreted from both epinephrine- and norepinephrine-containing cells in culture.

As was demonstrated previously for the perfused adrenal gland (Viveros et al., 1979, 1980), OPs and CAs were secreted proportionally from chromaffin cells in culture. This co-secretion of OPs and CAs occurred in response to a variety of secretagogues that induce secre-

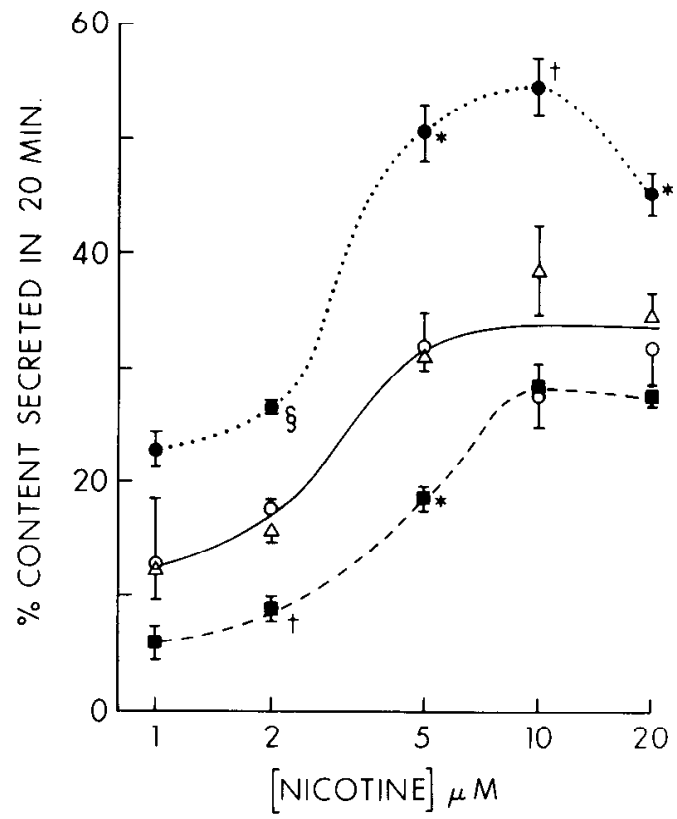

Figure 2. The concentration dependence of nicotine-induced secretion of epinephrine, norepinephrine, and opioid peptides from chromaffin cells. Chromaffin cells were incubated in the presence of the indicated concentrations of nicotine for $20 \mathrm{~min}$. The chromaffin cell catecholamines were $64 \pm 1 \%(n=24)$ epinephrine. The symbols used are: norepinephrine, ; epinephrine, $\square$; norepinephrine plus epinephrine, $\triangle$; and opioid peptides, $O$. The data are shown as the mean $\pm \mathrm{SEM} ; n=3$. Statistically significant differences of catecholamine secretion when compared to opioid peptide secretion are $*, p<0.025 ; \dagger$, $p<0.005$; and $\S, p<0.001$. 
tion of chromaffin vesicle contents from adrenal medullary cells (Fenwick et al., 1978; Kilpatrick et al., 1980a; Conn et al., 1980; Ledbetter and Kirshner, 1981). This cosecretion of OPs and $\mathrm{C} \Lambda \mathrm{s}$ is strictly dependent on extracellular calcium (Table III; Wilson et al., 1981d; Livett et al., 1981) and is activated by the calcium ionophore, Ionomycin, in a concentration-dependent fashion (Wilson et al., 1981d). This calcium-dependent co-secretion from chromaffin cells differs from secretion by cultured human pheochromocytoma cells (Wilson et al., 1981d). In these tumor cells, the secretion of OPs and CAs was not proportional under all conditions examined. The present studies support the conclusion that the secretion of CAs and OPs by human pheochromocytoma cells is not representative of normal adrenal medullary secretion.

Alteration of the CA and OP contents of the chromaffin cells by treatment with CA-depleting drugs allowed us to explore the mechanism of chromaffin cell secretion further. The secretion of OPs and CAs was proportional to the cell content of these substances. These results suggest that OPs which are newly synthesized following treatment with reserpine or tetrabenazine (Wilson et al., 1980, 1981a) are stored in secretion-competent vesicles. The failure of reserpine treatment to alter the subcellular distribution of chromaffin cell opioid peptides (Wilson et al., 1981b) is consistent with this suggestion. The results indicate that secretion is a function of the OP and CA content of the cells; regulation of adrenal medullary OPs and CAs may control the amounts of these neurohormones which are secreted. If newly synthesized OPs are stored in new vesicles, increased OP secretion also may reflect the increased number of vesicles. Therefore, these findings support the exocytotic theory of adrenal medullary secretion.

Our results also show that peptides containing cryptic opiate activity, and presumably enkephalin sequences (Lewis et al., 1980), are not only secreted from chromaffin cells as previously shown (Rossier et al., 1981) but are secreted in the same proportion of their cellular content as are CAs and OPs. Because these peptides range in molecular mass up to 22,000 daltons (Lewis et al., 1980; Rossier et al., 1981; Fig. 1), these results strongly suggest that the entire content of the chromaffin vesicle is secreted as also was suggested by the co-secretion of CAs and dopamine $\beta$-hydroxylase from chromaffin cells (Fenwick et al., 1978; Ledbetter and Kirshner, 1981) and the perfused adrenal (Viveros et al., 1969).

In contrast to immunohistochemical evidence (Livett et al., 1981) that enkephalins may be co-stored only with epinephrine, but not with norepinephrine, in the intact bovine adrenal medulla, these studies show that $O P$ secretion is proportional to total CA secretion but not to that of either amine alone. Our results suggest that OPs are stored both in cells that contain norepinephrine as well as those that contain epinephrine. Livett et al. (1981) also showed that Leu-enkephalin immunoreactivity is secreted in proportion to epinephrine rather than to norepinephrine. Possible explanations for this apparent discrepancy with our work include: (1) degradation of secreted Leu-enkephalin or (2) differential storage of Leu-enkephalin, but equal storage of total opiate activity, in the two cell types.
Our findings suggest that stimulation of the adrenal medulla in vivo results in the exocytotic secretion of Metenkephalin, Leu-enkephalin, and a variety of enkephalinrelated peptides into the circulation. These peptides may be effective in complementing or modulating the actions of secreted CAs or may have unrelated functions. Certainly, elucidation of the actions of these secreted peptides is necessary before the role of the adrenal medulla in homeostasis and in responding to stress can be understood completely.

\section{References}

Anton, A. H., and D. F. Sayre (1962) A study of the factors affecting the aluminum oxide-trihydroxyindole procedure for the analysis of catecholamines. J. Pharmacol. Exp. Ther. 138: 360-375.

Chang, K. -J., and P. Cuatrecasas (1979) Multiple opiate receptors: Enkephalins and morphine bind to receptors of different specificity. J. Biol. Chem. 254: 2610-2618.

Clement-Jones, V., P. J. Lowry, L. H. Rees, and G. M. Besser (1980) Met-enkephalin circulates in human plasma. Nature 283: 295-297.

Conn, P. M., D. Kilpatrick, and N. Kirshner (1980) Ionophoretic $\mathrm{Ca}^{2+}$ mobilization in rat gonadotropes and bovine adrenomedullary cells. Cell Calcium 1: 129-133.

Fenwick, E. M., P. B. Fajdiga, N. B. S. Howe, and B. G. Livett (1978) Functional and morphological characterization of isolated bovine adrenal medullary cells. J. Cell Biol. 76: 12-30.

Govoni, S., I. Hanbauer, T. D. Hexum, H. -Y. T. Yang, G. D. Kelly, and E. Costa (1981) In vivo characterization of the mechanisms that secrete enkephalin-like peptides stored in dog adrenal medulla. Neuropharmacology 20: 639-645.

Kilpatrick, D. L., F. H. Ledbetter, K. A. Carson, A. G. Kirshner, R. Slepetis, and N. Kirshner (1980a) Stability of bovine adrenal medulla cells in culture. J. Neurochem. 35: 679-692.

Kilpatrick, D. L., R. V. Lewis, S. Stein, and S. Udenfriend (1980b) Release of enkephalins and enkephalin-containing polypeptides from perfused beef adrenal glands. Proc. Natl. Acad. Sci. U. S. A. 77: 7473-7475.

Ledbetter, F. H., and N. Kirshner (1981) Quantitative correlation between secretion and cellular content of catecholamines and dopamine- $\beta$-hydroxylase in cultures of adrenal medulla cells. Biochem. Pharmacol. 30: 3246-3249.

Lewis, R. V., A. S. Stern, S. Kimura, J. Rossier, S. Stein, and S. Udenfriend (1980) An about 50,000-dalton protein in adrenal medulla: A common precursor of [Met]- and [Leu]enkephalin. Science 208: 1459-1461.

Livett, B. G., D. M. Dean, L. G. Whelan, S. Udenfriend, and J. Rossier (1981) Co-release of enkephalin and catecholamines from cultured adrenal chromaffin cells. Nature 289: 317-319.

Mizobe, F., V. Kozousek, D. M. Dean, and B. G. Livett (1979) Pharmacological characterization of adrenal paraneurons: Substance $P$ and somatostatin as inhibitory modulators of the nicotine response. Brain Res. 178: 555-566.

Rossier, J., D. M. Dean, B. G. Livett, and S. Udenfriend (1981) Enkephalin congeners and precursors are synthesized and released by primary cultures of adrenal chromaffin cells. Life Sci. 28: 781-789.

Schultzberg, M., J. M. Lundberg, T. Hökfelt, L. Terenius, J. Brandt, R. P. Elde, and M. Goldstein (1978) Enkephalin-like immunoreactivity in gland cells and nerve terminals of the adrenal medulla. Neuroscience 3: 1169-1186.

Stine, S. M., H. -Y. T. Yang, and E. Costa (1980) Release of enkephalin-like immunoreactive material from isolated bovine chromaffin cells. Neuropharmacology 19: 683-685.

Trifaró, J. M., and R. W. H. Lee (1980) Morphological charac- 
teristics and stimulus-secretion coupling in bovine adrenal chromaffin cell cultures. Neuroscience 5: 1533-1546.

Viveros, O. H., L. Arqueros, and N. Kirshner (1969) Quantal secretion from adrenal medulla: All-or-none release of storage vesicle content. Science 165: 911-913.

Viveros, O. H., E. J. Diliberto, Jr., E. Hazum, and K. -J. Chang (1979) Opiate-like materials in the adrenal medulla: Evidence for storage and secretion with catecholamines. Mol. Pharmacol. 16: 1101-1108.

Viveros, O. H., E. J. Diliberto, Jr., E. Hazum, and K. -J. Chang (1980) Enkephalins as possible adrenomedullary hormones: Storage, secretion, and regulation of synthesis. Adv. Biochem. Psychopharmacol. 22: 191-204.

Wilson, S. P., and O. H. Viveros (1981) Primary culture of adrenal medullary chromaffin cells in a chemically defined medium. Exp. Cell Res. 133: 159-169.

Wilson, S. P., K. -J. Chang, and O. H. Viveros (1980) Synthesis of enkephalins by adrenal medullary chromaffin cells: Reser- pine increases incorporation of radiolabeled amino acids. Proc. Natl. Acad. Sci. U. S. A. 77: 4364-4368.

Wilson, S. P., M. M. Abou-Donia, K. -J. Chang, and O. H. Viveros (1981a) Reserpine increases opiate-like peptide content and tyrosine hydroxylase activity in adrenal medullary chromaffin cells in culture. Neuroscience $6: 71-79$.

Wilson, S. P., K. -J. Chang, and O. H. Viveros (1981b) Opioid peptide synthesis in bovine and human adrenal chromaffin cells. Peptides (N. Y.) Suppl. 12 : 83-88.

Wilson, S. P., R. Slepetis, K. -J. Chang, N. Kirshner, and O. H. Viveros (1981c) Secretagogues that act by different mechanisms induce secretion of opioid peptides and catecholamines from chromaffin and pheochromocytoma cells. Soc. Neurosci. Abstr. 7: 103.

Wilson, S. P., R. Slepetis, K. -J. Chang, N. Kirshner, and O. H. Viveros (1981d) Differential secretion of opioid peptides and catecholamines from cultured cells of a human pheochromocytoma tumor. Life Sci. 29: 2257-2264. 